\title{
Personal and Spatial Deixes amid Foreign Students in Muhammadiyah University of Purwokerto
}

\author{
Iis Nafisah ${ }^{1}$, Andayani ${ }^{2}$, Nugraheni Eko Wardani ${ }^{3}$
}

\begin{tabular}{l} 
ARTICLE INFO \\
\hline Article History: \\
Received 08.10.2018 \\
Received in revised form \\
11.01 .2019 \\
Accepted \\
Available online 01.04 .2019
\end{tabular}

\begin{abstract}
This study aimed at investigating personal and spatial deictic expressions in the uses of Indonesian lang uage by the foreign students in Muhammadiy ah University of Purwokerto (UMP). These foreign students were the learners who came from various countries that learned Indonesian language in UMP. A descriptive qualitative method was used in this study. The findings indicated that the inappropriate uses of personal deixis in Indonesian language applied by the foreign students entailed: a) the incorrect uses of pronouns 'saya', 'aku', 'Anda' and 'kamu', b) the mistakes in sentence arrangement, c) the translation from English lang uage which was dominantly used, and d) the incorrect uses of second person pronoun. In the meantime, the incorrect uses of spatial deixis were found in the words 'ini', 'itu', and 'di sana'. The foreign students found it difficult to learn deixis in the light of various vocabulary choices of Indonesian language so that they ended up with confusion. The inappropriate uses of personal deixis were dominantly encountered because the foreign students were confronted with the difficulties in using the first person, second person, and third person of personal deixis in their daily Indonesian communication.
\end{abstract}

(C) JERE. All rights reserved

Keywords: ${ }^{1}$

Personal deixes, spatial deixes, Indonesian language for foreign users (BIPA)

INTRODUCTION

The relationship among human beings is built up through the presence of a language. Acording to Tonapa, Anwar, and Mantasiah (2018: 56) language becomes a tool that mediates humans to be able to properly interact with one another. Language is of paramount importance since through using a language humans can interact with one another, including an interaction between ones and the foreigners. An interaction or communication established between ones and the others is defined by Boztepe (2017:27) as a way of sharing thoughts, feelings, and interconnectedness with people. Humans learn a number of languages in order to manage to establish appropriate communication with other human beings in the world. Hence, the type of language is split into two categories, namely the first language and the second language. Such second language is really necessary for the sake of being capable of understanding others.

Nowadays, a lot of foreign students who are interested in learning Indonesian Language directly come to Indonesia. Their interest is anchored in not only the Indonesian language per se but also the lives of Indonesian people that they intend to know further. Today, the learning of Indonesian language for foreign users (in Indonesian term abbreviated as BIPA) is gaining a significant improvement. This point is also conveyed by Purwiyanti et al. (2017: 161) in their study which reveals that the development of Indonesian language learning for foreign users occurs not only domestically but also abroad. A couple of countries in the world make Indonesian language either as a learning subject or as a compulsory subject in tertiary education within their educational curriculums. This condition is advantageous since the more foreign users use Indonesian language; the bigger opportunity will exist in a way to internationalize Indonesian language.

The high level of foreigners' interest in learning Indonesian language and culture must be appreciated positively because in such a way we can internationalize Indonesian language in front of the world (Andayani \& Gilang, 2015:197). Culture, as the legacy left by ancestors, seems to attract foreign students' interest in learning Indonesian culture as well. Ardiansyah, Suharno, and Trianto (2018: 48) point out that culture becomes an inseparable part of humans' lives. It will continuously exist and rise amid humans' lives. This condition is what drives foreign students to be interested in the Indonesian culture as well. This condition should be appreciated, including they learn Indonesian language for an academic purpose. The Indonesian language as the second language for them is absolutely not easy to be acquired, and it is also not easy to be taught by the teachers. Both processes, Indonesian language acquisition and teaching, take time and need some appropriate approaches in order that the learning processes can be more comprehensible and work smoothly for both the foreigners as the learners and the teachers. According to Budia sih, Andayani \&

\footnotetext{
${ }^{1}$ Corresponding e-mail: nafisahiis577@gmail.com, orchid.org/0000-0001-9581-2439

2: orchid.org/0000 $00025233805 \mathrm{X}$

3; orchid.org/0000-0002-8051-2289

Sebelas Maret University, Surakarta, Indonesia ${ }^{1,2,3}$
} 
Rohmadi (2017: 214), the simplest way to capably master a second language is by using that language in daily lives covering various language components such as words, simple sentences, and up to the more complex words as well as sentences. Thus, amid a number of popular universities in Indonesia such as, one of them, Sebelas Maret University, it necessitates the foreign students to communicate using Indonesian language in their daily lives. It is in line with Saddhono's (2012: 177) statement in his study which utters that foreign students who learn Indonesian language in Sebelas Maret University are demanded to master Indonesian language as their second language. The mistakes and errors in using a language will definitely exit. Hence, it is needed an effort made to suppress even up to the smallest mistakes and errors in language use.

Foreign students learn a lot of things about Indonesian language including a topic as regards deixis. Deixis per se is not a novel thing for the students of Indonesian Language Education Department. Deixis is a subset of pragmatics which addresses about pointing w ords or references. Deixis falls into several categories as follows: personal deixis which is associated with pronouns, spatial deixis that relates to the words expressing places such as 'di sini', ' $d i s a n a$ ', and 'di situ', temporal deixis which is pertinent to the words expressing time such as 'tadi', 'besok', 'nanti', and 'kemarin', discourse deixis that concerns with some references to particular parts in a given or ongoing discourse, and social deixis which corresponds to social differences between the speaker and the interlocutor (Cummings, 2007:31-41).

Deixis is not an easy case when it is applied by foreign students. They likely feel confused while applying deixis in daily communication. This barrier aligns with Saddhono (201: 177) in his study stating that the errors or mistakes in language use will certainly exist, hence it is necessary for an effort to suppress the errors or mistakes made by foreign students as minimally as possible. The researcher encountered this phenomenon among foreign students who were learning Indonesian language in Muhammadiyah University of Purw okerto. The researcher had observed the learning processes that they dealt with and had also conducted interviews with the students vis-a-vis the application of deixis in daily communication. The researcher found out some foreign students who had not yet been able to correctly use personal and spatial deixes. They felt confused with too many vocabularies existing in the Indonesian language. For instance, the word 'saya' is used when communicating in a formal agenda or when communicating with older interlocutors. The words, 'di sana' and 'itu', are used to point out a thing whose distance is far from the speaker. Grounded in the encountered phenomenon, the researcher chooses a study topic addressing personal and spatial deixes in the use of Indonesian language by foreign students in Muhammadiyah University of Purw okerto.

The studies oriented towards deixis have been numerously conducted. One of them is such a study undertaken by Nurdini (2017: 149-162) whose focus is on the uses of deixis in an English language textbook for tenth grade of 2013 curriculum. Her study was carried out to reveal the kinds and meanings of deixis used in the aforementioned textbook. The phenomenon underlying her study was the lack of students' understanding related to deixis. In addition, her study was executed in order to manage to give a sort of input wherein the uses of deixis among students could become a tool to improve their pragmatic ability. Another study is also conducted by Kennedy (2012: 73-87) who analyzes the use of spatial deixis 'disini' in Robert Creeley's poem. Kennedy argued that Robert Creeley's poem was not yet able to apply the proper uses of the words 'di sini' and ' $d i$ sana'. That poem used the word 'di sini' several times. Notwithstanding, the uses of that word were not in line with the contexts of the referred locations in the poem.

The study regarding deixis has also been conducted by Tonapa, Anwar, and Mantasiah (2018:55) who address about the mistakes of using deixis in simple essays written in German language. The findings of their study revealed that the mistakes in using personal deixis entailed those of using personal pronouns and possessive pronouns which were respectively within nominative and accusative cases, wherein there were a total of 97 mistakes $(84.35 \%$ ) with a very high category; those of using temporal deixis were found as many as 3 mistakes with the percentage of $2.61 \%$ and were categorized as almost no mistakes; and those of using spatial deixis were found as many as 15 mistakes (13.04\%) with the least category. The frequency of students' mistakes in using personal deixis found in their simple essays written in German language was more dominant if compared to their mistakes in using temporal and spatial deixes. The other study which addresses the mistakes of using deixis has also been executed by Afifah and Widodo (2015:27) whereby they orient towards the mistakes found in the uses of personal, spatial, and temporal deixes within tertiary students' essays at Niveau A2 in the German Literature Department of the State University of Malang along 
with finding out the influential factors. Their study revealed that there were encountered a variety of mistakes in connection with the uses of personal, spatial, and temporal deixes in the students' essays. The factors identified as the causes of those mistakes were overgeneralized interference, communication strategies, the elements of foreign language learning, the lack of contrast, students' socio-psychological conditions, domino effects, and redundancy.

In respect of the previous studies as mentioned above, it can be discerned that the uses of deixis take a slightly long time to be learned because the applications of deixis are not easy, or they probably gain less attention (Ansiska, Lasmono, \& Wartiningsih, 2013: 1). The aforementioned prior studies are the studies conducted to both Indonesian people and foreigners. Mostly the study results are not adequately good since the mistakes of using personal deixis are dominantly encountered, and then further mistakes are followed by the uses of temporal and spatial deixes. If such prior studies focus on scrutinizing deixis in overall, in the present study, the researcher is more interested in addressing about personal and spatial deixes inasmuch as the foreign students engaged as the objects of this study tend to find it more difficult to apply personal and spatial deixes.

\section{THEORETICAL BASES}

Deixis is a subset of pragmatics wherein pragmatics itself relates to the ability of using a language in making connection and harmony betw een sentences and the related contexts correctly (Levinson, 1983:1 -27). Deixis also corresponds to the contexts of communication which incline to the references of something. Putrayasa (2014: 38) states that deixis is a form of language in a kind of either words or sentences which are functional as references or certain functions outside the language per se. Djajasudarma (2010: 57) also accentuates that deixis is the most obvious way to draw on a connection between a language and the contexts within the structures of the language itself. In addition, Bublitz, W., \& Norrick, N. R (2011:315) state that deixis is also an important thing for pragmatics because it determines the intersection between the language structures and someone's social status.

Yule (2006: 13) explains that deixis is a technical term (derived from Greek word) for one of the intrinsic things that we do by using utterances. Deixis means 'pointing' through language. The forms of linguistics which are used to deal with such 'pointing' are called deictic expressions. When you are pointing at an object and then ask 'Apa itu?', it indicates that you are using a deictic expression as identified by 'itu' which is used to point at something suddenly in a particular context. The deictic expressions lie among some initial expressions commonly uttered by children and can also be used to point at a person through personal deixis (' $k u^{\prime}$ and ' $m u^{\prime}$ ), to refer to a place through spatial deixis ('di sini' and 'di sana'), or to refer to time through temporal deixis ('sekarang' and 'kemudian'). In the meantime, according to Purwo (1984: 10), a word is called deixis if its reference is fluctuating depending on who the speaker is and depending upon when and where there word is uttered, for instance the words 'saya', 'sini', and 'sekarang'. In overall, with regard to the definition of the term deixis, it is necessary to pay attention to the elements which contain referential and non-referential meanings.

Deixis falls into a couple of categories as follows: personal deixis which relates to pronouns, spatial deixis that corresponds to the words which express places such as 'di sini', 'di sana', and 'di situ', temporal deixis which concerns with the words that express time such as 'tadi', 'besok', 'nant'i, and 'kemarin', discourse deixis that is associated with the references to particular parts in a given or ongoing discourse, and social deixis which is pertinent to social differences between a speaker and the interlocutor (Cummings, 2007: 31 41). However, the present study only addresses about personal and spatial deixes. Deixis can be found in many cases either in a conversation between a speaker and the interlocutor, in writing of newspapers, in students' essays at school, or in fictional works. Deixis also has a function of referring to something. Thus, the success of an interaction between a speaker and the interlocutor to a greater or lesser extent will depend upon the understanding of deixes which is used by the speaker (Nadar, 2009: 55).

Indonesian language for foreign users is currently gaining an increase. This does not rule out the possibility that it will continuously increase every year. This point is supported by Sari (2018: 122) in her study that states that there are relatively many countries carrying out Indonesian language learning for foreign users (BIPA). This condition becomes advantageous to Indonesian language because a lot of foreign students who have interests in learning Indonesian language. Indonesian language playing a role as a second language for foreigners triggers their interest in learning it more deeply and comprehensively. 
Besides learning about the Indonesian cultures and the whole aspects of Indonesian people's lives, they also learn how to use Indonesian language in their daily communication. The presence of language differences causes the foreign students to be confronted with difficulties in using Indonesian language. The foreign students assume that there are found a quantity of Indonesian vocabularies that make them difficult, and it takes a long time to learn Indonesian language. Based on the difficulties faced by the foreign students, the researcher has found out the mistakes or errors they make specifically in using deixis or referential words when they use Indonesian language.

In this study, the researcher will discuss deixis from the aspect of utterances. Those utterances are taken from the activities done by the foreign students who are learning Indonesian language in Muhammadiyah University of Purwokerto. The researcher records the learning activities carried out by those foreign students so that this way helps the researcher easily analyze the data.

Based on the study result, it is found that deixis seems difficult to be applied in the foreign students' daily communication when they are using Indonesian language. They find it difficult because there are many varieties of Indonesian vocabularies especially in the use of pronouns or personal deixis. Therefore, they will take a relatively long time to manage to appropriately apply deixis. Indonesian language for foreign students can be categorized as their second language. It means that the teaching of Indonesian language for foreign users (BIPA) becomes different from the Indonesian language teaching commonly experienced by native Indonesian students. Johnson (2008: 10) states that the existence of someone's interest in learning a second language is also influenced by his/her environment. He/she can become interested in it more than merely in his/her native language. Such interest is also triggered by the cultures prevailing to several countries so that he/she is willing to learn. The difficulties in using deixis as faced by the foreign students become a resource of evaluation for the Indonesian language teachers especially in order to become more meticulous in giving sufficient understanding to the foreign students. These foreign students will definitely face more challenges in learning because they are not accustomed to using many vocabularies.

\section{METHOD}

The kind of this study was a descriptive qualitative study. The approach used in this study was a case study. A case study is a strategy of inquiry wherein the researcher meticulously investigates a program, events, activities, processes, and a group of individuals (Creswell, 2014: 20). The data in this study referred to the foreign students' utterances which reflected the uses of personal and spatial deixes. The data which the researcher solicited were in the form of foreign students' utterances specifically for those aging in a range from 22 to 25 years old. They were some foreign students coming from France, Korea, and Thailand, and who were learning Indonesian language at a beginner level. In addition, the sources of data were several foreign students engaged as the informants. Informants are defined as the people who are involved to give a set of information vis-a-vis the situation or condition of the research field (Moleong, 2014: 157). The data were garnered through observation and interactive as well as in-depth interviews. The data credibility was reached by doing triangulation method using the references such as interview records and videos of observation. This study was conducted in Muhammadiyah University of Purwokerto. The data analysis used extralingual equivalent method. According to Mahsun (2012: 260), extralingual equivalent method is a method of data analysis which is done by connecting and comparing the elements outside a language such as references, the contexts of utterances, the social contexts of language use, and the language users viewed from various bounded-criteria such as gender, age, social class, and etc.

\section{FINDING}

Personal and spatial deixes in the Indonesian language used by foreign students were found in the data sources as identified through interviewing and observing their learning processes. The uses of personal deixis were found more than those of spatial deixis. With respect to the uses of personal deixis, the following data were found: a) the incorrect uses of pronouns 'saya', ' $a k u^{\prime}$ ', 'Anda' and ' $k a m u$ ', b) the mistakes or errors in sentence structures, c) a translation from English language which was dominantly used, and d) the inappropriate uses of second person pronoun. In the meantime, Appertaining to the uses of spatial deixis, the incorrect or inappropriate uses of the words ' $i n i$ ', 'itu', and 'di sana' were found. Anchored in the findings, the following details will provide the related discussion. 
Nafisah,I., Anday ani \& Wardani,N.E. (2019). Personal and spatial deixes amid foreign students in Muhammadiy ah University of Purwokerto, International Journal of Educ ational Research Review,4(2),86-96.

\section{The Uses of Personal Deixis}

Personal deixis portrays pointing words which refer to the individual roles of a speaker and the interlocutor. Grounded in the study which was done, it was found several cases as regards the uses of personal deixis or pronouns which had not yet been able to be appropriately applied by the foreign students in their daily Indonesian communication. The uses of personal deixis such as 'saya', 'aku', 'Anda' and 'kamu' were found to be incorrectly used as view ed from several learning periods that they dealt with.

The use of personal deixis such as ' $a k u$ ' and 'saya' within one sentence as done by one of the foreign students in this study was considered less effective because he in this sense placed someone in both formal and informal condition in an ongoing interaction. In fact, if anchored in the real context of that interaction, the communication that he was dealing with at that time ran in a formal condition, and the speaker was speaking with someone older. In Indonesian language, the degree of politeness in communication with other people should be made really attentive. Indonesian people put themselves appropriately in connection with whom they are speaking with in order that the communication runs well. How ever, the foreign student as depicted above had not been able to appropriately use personal deixis based on the context of uttera nce. As one of the identified conditions, when the learning process was going on, that foreign student, without his realization of having made such mistake, was smoothly talking to his teacher as shown in the following excerpt.

\section{Data 1}

X : Oh begitu. Saya lihat Bahasa Indonesia kamu sudah lancar. Bagaimana cara kamu belajar Bahasa Indonesia?

Y : Iya saya belajar dari teman-teman kelas saya. Ketika masih aw al, aku sering pergipergi sendiri ke suatu tempat dengan membawa pocket dictionary. Jadi aku belajar sendiri.

$\mathrm{X} \quad$ : Well, I see that your Indonesian language has been fluent enough. How do you learn Indonesian language?

Y : Yes, I learn from my classmates. At the beginning, I often went out alone to a place alongside taking my pocket dictionary with me. So, I learned by myself.

Based on the above data, this foreign student used personal deixis 'aku' twice. He did not pay attention to whom he was speaking with. In the previous sentence, he had been able to use personal deixis or pronoun 'saya' in the formal context of utterance. Such condition could be considered common if he just did it once. In fact, after being observed, he seemed to have not yet been capable of positioning himself appropriately in association with whom he was speaking with.

In addition, the incorrect use of personal deixis ' $k a m u$ ' when communicating with older interlocutor $\mathrm{w}$ as also found. This case happened when a foreign student was asking about the book that the teacher had read insofar as the time of speaking. Notwithstanding, while asking, this foreign student did not position himself conveniently in accordance with whom he was speaking with.

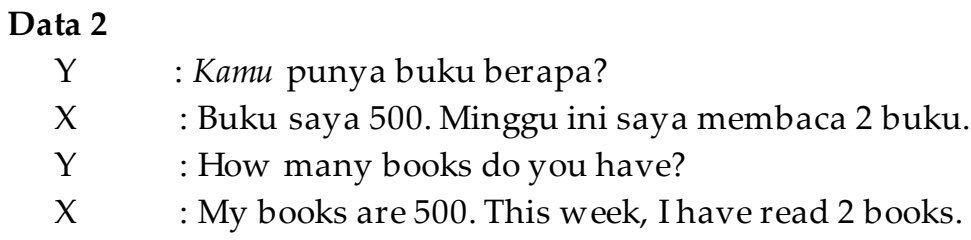

These second data indicated the use of personal deixis 'kamu' in an incorrect context. It was incorrect, given that at the time the interaction was going on, he was interacting with his teacher. He was asking how many books the teacher had already read. Such use of personal deixis in this sense was definitely inappropriate since the teacher was someone older than the foreign student perse. There should be a proper way of self-positioning when interacting with a teacher. 
The other case concerned with the omission of singular first-person pronoun at the personal deixis 'saya' in a sentence structure leading to generate an ineffective sentence. The omission of a word in a sentence would result in an ineffective sentence. Using an effective sentence was of paramount importance for the sake of avoiding some sort of inefficient meaning construction from that sentence.

Data 3

$\begin{array}{ll}\mathrm{X} & \text { : Anda tidak capek membaca } 70 \text { halaman? } \\ \mathrm{Y} & \text { : Tidak. Tidak capek. } \\ \mathrm{X} & : \text { Don't you feel tired of reading } 70 \text { pages? } \\ \mathrm{Y} & : \text { No, I don't }\end{array}$

In the third data above, an ineffective sentence was found to be used by a foreign student while interacting with a teacher. This foreign student answered shortly without paying attention to the proper sentence arrangement. The sentence ('Tidak. Tidak capek') would be more acceptable if added by the first personal pronoun of personal deixis, namely 'saya' at the beginning of the second sentence, so that the sentence could be 'Tidak. Saya tidak capek'. If such sentence modification was made, the sentence per se would be effective, and the proximal social connection between the foreign student and the teacher would be wellcreated.

The other case in regard to the incorrect use of personal deixis was also encountered, wherein it resulted in an incorrect arrangement of sentence structure. In this case, one of the foreign students did not properly apply a sentence structure on the basis of the correct use of Indonesian language. He used a translation from English language without taking into account the appropriate rules of Indonesian language.

\section{Data 4}

$$
\begin{aligned}
& \text { X: Cyril, Apakah Anda punya hobi? } \\
& \text { Y :Saya. Punya hobi. Saya hobi membaca buku. Berenang. } \\
& \mathrm{X} \quad \text { : Cyril, do you have a hobby? } \\
& \mathrm{Y} \quad \text { : I have a hobby. My hobby is reading books and swimming }
\end{aligned}
$$

The fourth data above indicated the incorrect arrangement of an Indonesian language sentence. The sentence 'saya hobi' was a translation of English language from 'my hobby'. Such incorrect sentence arrangement resulted in the incorrect meaning construction as well. This case could become a habit if it was not corrected by the teacher.

Furthermore, an ineffective sentence arrangement was also encountered in the other learning process. An ineffective arrangement of a sentence became an error which should not be done because the process of communication would be unclear and shift from the actual goal. An effective sentence arrangement should be applied in communication specifically within the interaction with someone older. It should be done in order that the communication did not run ambiguously.

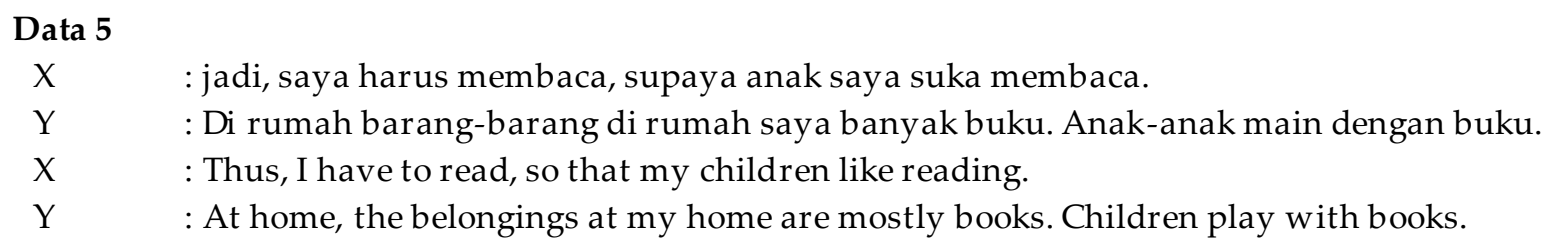

As depicted in the fifth data above, the recurrence of the words 'di rumah' $w$ as found so that it resulted in an ineffective sentence arrangement. Repeating words in a particular condition was indeed necessary in order to emphasize a certain part of an utterance which w as considered important. How ever, as manifested in the above data, such word repetition done by this foreign student even led to make the sentence ineffective.

The other case showed that the Indonesian word arrangement was still derived from an English translation. Principally, the arrangement of words between Indonesian and English language is mostly 
Nafisah,I., Anday ani \& Wardani,N.E. (2019). Personal and spatial deixes amid foreign students in Muhammadiy ah University of Purwokerto, International Journal of Educ ational Research Review,4(2),86-96.

different. The arrangement of Indonesian words derived from an English translation dominantly makes a reversed word placement. Among the foreign students who learned Indonesian language in Muhammadiyah University of Purwokerto were also found those who uttered Indonesian language based on the translation of English language, whereby it resulted in incorrect meaning making. One of those can be seen in the following excerpt.

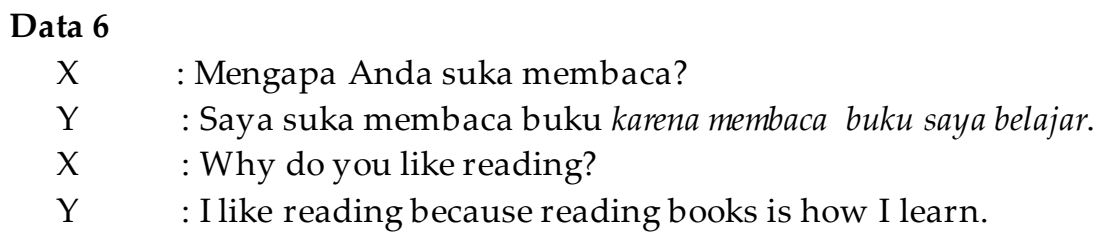

The sixth data above portrayed an inappropriate sentence structure. Such structure was derived from an English translation. This foreign student did not apply the struct ure of Indonesian language on the basis of its proper rule. As depicted, he answered the question posed by the teacher merely by translating English to Indonesian language.

The next case, the second person pronoun of a personal deixis 'Anda' was incorrectly used to point at 'saya' as the first person pronoun. Such incorrect use of personal deixis absolutely would generate a completely different meaning construction from the actual intention of the two persons' talk. Such incorrect use of personal deixis was done by a foreign student when he was telling the teacher that his grandfather had read a lot of books. However, what he said was 'kakek Anda membaca banyak buku' meaning that the teacher's grandfather was who had read lots of books. In fact, what he actually meant was not that way.

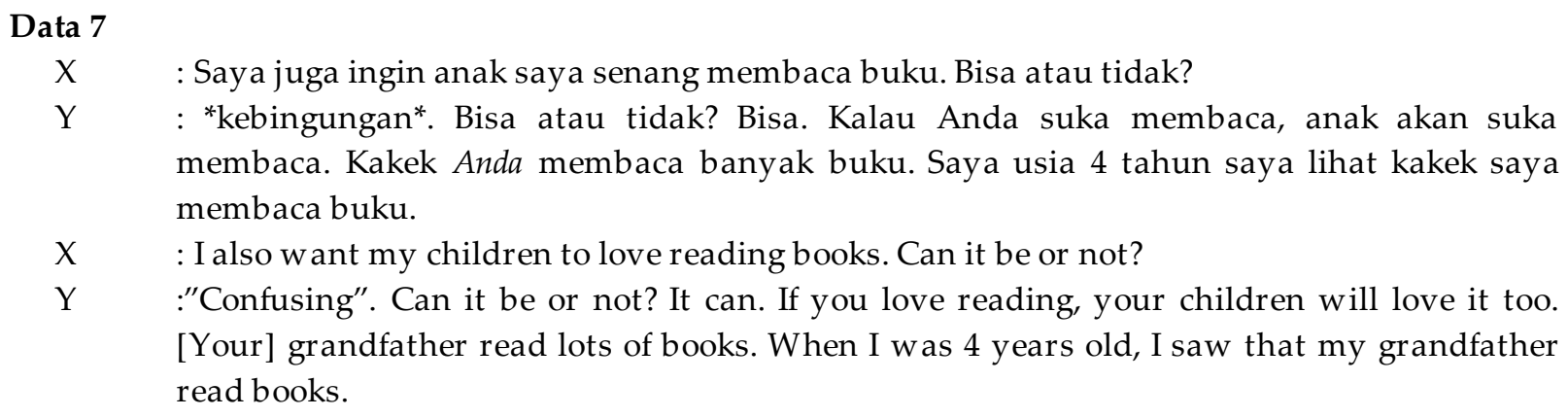

Based on the seventh data above, it was clear that the foreign student $w$ as intentionally telling about his grandfather whohad read a lot of books since he was 4 years old. Notwithstanding, what hap pened was that this foreign student incorrectly used the second-person pronoun of personal deixis 'Anda' which brought referential information that the teacher's grandfather was the one told to have read lots of books. That was not the student's actual intention though. Thus, the sentence brought a different set of meaning making from the actual intention of the talk.

Regarding the data which the researcher has gained vis-a-vis the uses of personal deixis, it can be summarized that there are a quantity of deficiencies in the uses of personal deixis done by the foreign students in their daily Indonesian communication. The foreign students have not completely understood and comprehended how an effective sentence arrangement of Indonesian language should be made. However, these foreign students still keep learning in order to manage to apply the rules of Indonesian language on the basis of the proper sentence arrangement.

\section{The Uses of Spatial Deixis}

Spatial deixis refers to giving a reference to a location based on the speaker's intention in a language use. Yule (2006: 20) states that while mulling over the spatial deixis, it is of importance to bear in mind that a place, from the speaker's perspective, can be referred to both mental and physical object. In this study, the uses of inappropriate spatial deixis were found. The foreign students who were progressively learning Indonesian language had not yet sufficiently understood the uses of spatial deixis such as 'ini', 'itu', 'sini', 'situ', or 'sana'. Such incorrect uses resulted in shifting the sentence meaning. The following details will 
present the uses of spatial deixis in Indonesian language by the foreign students in Muhammadiyah University of Purwokerto.

One of the cases was the use of the word 'ini' to indicate an object which was far in distance. On the basis of its actual principle, the word 'ini' was used to point at an object which was close but not far in distance. How ever, this study found that one of the foreign students used the word 'ini' to refer to an object that $w$ as far in distance so that the sentence became ineffective.

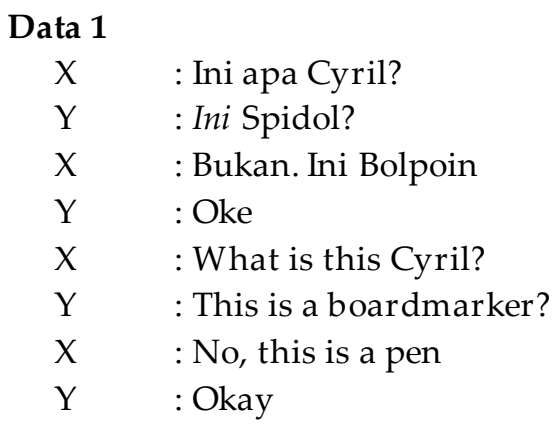

The first data above were taken from a learning situation which addressed about the use of the words 'ini' and 'itu'. The teacher asked that foreign student through posing a question 'ini apa Cyril?' while showing a pen he was holding. From that question, Cyril answered 'ini spidol?'. In fact, in that situation, the teacher's position was quite far from her, but she came up with answering the question using the word 'ini' which meant that she just repeated the word previously uttered by the teacher. Putraya sa (2015: 48) states that when something pointed lies slightly far from the speaker, the word 'situ' or 'itu' should be used.

The subsequent case $w$ as the inappropriate use of the word 'di sana'. Spatial deixis in the word 'di sana' w as used to refer to an object which was far from the interlocutor. How ever, this case seemed to have not yet been able to be applied by the foreign students. They were still confused with using the words 'disana' and 'di sini' on account of being considered similar. The following excerpt portrays this issue.

\section{Data 2 \\ X : Dimana pulpen kamu Cyril? \\ Y : Pulpen saya di sana. \\ $\mathrm{X} \quad$ : Where is your pen, Cyril? \\ $\mathrm{Y}:$ : My pen is there}

If viewed from the dialog in the above excerpt, the conversation did not sound incorr ect. However, if compared to the exact situation when the conversation took place, the student's answer from the given question was not correct. That foreign student used spatial deixis 'di sana' to point at an object which was close to her. The teacher asked 'di mana pulpen kamu Cyril?', and then she answered 'pulpen saya di sana'. In fact, what Cyril meant exactly existed in front of her. She admitted that she was still confused with using spatial deixis 'di sana' and 'di sini'.

The other case was associated with the use of spatial deixis 'ini' dan 'itu'. The case of such spatial deixis was concerning with the close and far distance of an object. This case was probably easy for native Indonesian people but not for foreign students. The researcher found some foreign students who had not yet been able to use spatial deixis properly. The following portrayal depicts one of the foreign students who had not understood spatial deixis.

\section{Data 3}
$\mathrm{X} \quad$ : Itu buku apa?
Y : Itu buku cerita kriminol (kriminal). Buku itu menang lomba. Buku ini menang lomba.
$\mathrm{X} \quad$ : What book is that?
Y : That is a crime story book. That book w as from winning a competition. This book was from winning a competition. 
Nafisah,I., Anday ani \& Wardani,N.E. (2019). Personal and spatial deixes amid foreign students in Muhammadiy ah University of Purwokerto, International Journal of Educ ational Research Review,4(2),86-96.

The third data above showed a foreign student's confusion while using spatial deixis 'ini' and 'itu'. He repeated his sentences twice with merely replacing the word 'itu' to be 'ini'. In the second sentence, this foreign student had correctly used spatial deixis since the book which was told was on his hand. It meant that the book was in a close distance. That $w$ as why the word 'in' $i$ had to be used. The occurrence of such sentence repetition implied that this foreign student $w$ as hesitant about using the word ' $i t u$ ', so he repeated his sentence by using the word 'ini'.

Based on the data of spatial deixis which the researcher has gained, it can be summarized that spatial deixis is also not an easy thing to be used by the foreign students. It is in the light of the words in the spatial deixis which are relatively similar so that this condition leads to the foreign students' confusion. The issue of spatial deixis is oriented tow ards the distance of an object which is close or far. The use of spatial deixis is probably easy for native Indonesian people but not for the foreign students.

\section{RESULT AND DISCUSSION}

Both personal and spatial deixes are not a sort of novel realm, but they were assumed to be a new topic by the foreign students who were learning Indonesian language in Muhammadiyah University of Purwokerto. They found it difficult to apply deixes because there were so many vocabularies of Indonesian language, so they were often trapped in fallacies. Afifah and Widodo (2015:27) explain that there are a range of influential factors leading foreign students to have difficulties in using deixes. They entail: interference, overgeneralization, communication strategies, the elements of foreign language learning, the lack of contrasts, the socio-psychological conditions of learners, domino effects, and redundancy. The foregoing was almost similar to the foreign students whom the researcher studied, wherein they also emphasized that a lot of varieties of Indonesian vocabularies caused them to most often be trapped in confusion while using deixes.

Personal deixis refers to the referential words which represent the role of the speaker himself as $w$ ell as theinterlocutor. Resting on this study, there were encountered a couple of points pertinent to the personal deixis of pronoun which had not yet been capably applied by the foreign students in their daily communication. The uses of personal deixis such as "saya", "aku", "Anda" and "kamu" were evidently not applied properly within several learning periods. Besides, the use of personal deixis "aku and "saya" within one sentence or utterance was also found in this study, and such evidence manifested in a less-effective use because one of the foreign students in this study placed someone in both formal and informal condition at once within one set of interaction. In fact, the real context framing his communication at that time nuanced a formal condition, and he was talking to an older person. In Indonesia, the degree of politeness is highly considered while communicating with others. Indonesian people position themselves in accordance with whom they are speaking with for the sake of appropriate and successful communication. This point is accentuated by Gunaw an (2013:8) in his study that the politeness in language use is a factor which controls and maintains communication in order to be appropriate, delightful, and free of uselessness.

Other than the deixis of singular first-person pronoun, the researcher also found the improper use of the second-person pronoun "kamu" and "Anda". It was deemed improper because while the interaction took place, one of the foreign students was interacting with his teacher. As previously depicted, he was asking how many books the teacher had already read. This condition is definitely not appropriate inasmuch as the teacher is someone older than the foreign student himself. There needs a kind of acceptable selfpositioning while interacting with the teacher.

Spatial deixis is a means of giving reference to a location according to the communicants in a language event. Yule (2006: 20) accentuates that in taking account of the spatial deixis, it is essential to be remembered that a place, from a speaker's perspective, can be identified as a mental place and also a physical place. In this study, the improper use of spatial deixis was also encountered. The foreign students who were learning Indonesian language had not yet adequately understood the uses of spatial deixis such as ini, itu, sini, situ, or sana. Such improper uses generated some shifts of sentence or utterance meanings. 
Nafisah,I., Anday ani \& Wardani,N.E. (2019). Personal and spatial deixes amid foreign students in Muhammadiy ah University of Purwokerto, International Journal of Educ ational Research Review,4(2),86-96.

Associated with the spatial deixis ini and itu, the related matter addresses the thing which is close and far in distance. This matter of spatial deixis is probably easy to be used by native Indonesian people, but not all of the foreign students can do so. Putrayasa (2015:48) explains that if something referred is placed a littlebit far from the speaker, the word situ or itu is to be used. The spatial deixis for the word di sana is used to point at a thing which is far in distance from the interlocutor. How ever, such case had not been capably applied by the foreign students. They still got confused with using the words "di sana" and "di sini" because those words were perceived to be similar.

The problems as regards personal and spatial deixes as found amid the foreign students emerge in light of several factors, and one of them is the lack of Indonesian language mastery as their second or target language. A similar view point is also addressed by Afifah and Widodo (2015: 28) in which the phenomenon vis-a-vis the errors or mistakes in the use of a target language among foreign students lies because they have not yet sufficiently learned the structure of that language, or because they have not understood it yet. Afifah and Widodo (2015:28) also add that the errors or mistakes in language use are view ed as a part of a language learning process.

\section{CONCLUSION}

Anchored in the results of data analysis in this study, it can be concluded that the improper uses of personal and spatial deixes are found in Indonesian language use amid the foreign students who are learning Indonesia language in Muhammadiyah University of Purwokerto. There are found 7 data concerning with personal deixis and 3 data corresponding to spatial deixis. The improper uses of personal deixis are dominantly encountered because the foreign students have not managed to differentiate the uses of singular first-person personal pronoun such as "aku" and "saya", and the second-person personal deixis such as "kamu" and "Anda". The foregoing is influenced by the absence of politeness degree while using personal deixis in Indonesian language. They label themselves by " $\mathrm{I}$ ", whereas in Indonesian language there are some word choices such as $a k u$, saya, and daku. Each of those words is used depending on whom they are speaking with. Besides, the improper uses of spatial deixis found among the foreign students are caused by their confusion over the uses of demonstrative pronoun for places such as ini, itu, sini, situ, or sana. The foreign students are often trapped in fallacies while using spatial deixis.

\section{REFERENCES}

Afifah, L., \& Widodo, P. (2015). Kesalahan Deiksis dalam Karangan Mahasiswa pada Niveau A2 di Jurusan Sastra Jerman UM. LingTera, 2(1), 27-37.

Andayani \& Gilang, L (2015). The effectiveness of integrative learning based text book toward the local culture comprehension and Indonesian language skill of foreign students. Journal Humanities and Social Science, 5 (10), 197-207.

Ansiska, M., Lasmono, D., \& Wartiningsih, A. (2013). Penggunaan Deiksis Persona dan Tempat dalam Novel Supernova 1 Karya Dee. Jurnal Pendidikan dan Pembelajaran, 3(3), 1-15.

Ardiansyah, R., Suharno, \& Triyanto. (2018). Inheritance national culture through learning in elementary school at disruptive era: Case study in Surakarta Indonesia. International Journal of Educational Research Review, 3(4), 48-53.

Boztepe, Ö. (2017). The Adaptation of Student Communication Satisfaction Scale into Turkish Culture. International Journal of Educational Research Review, 2(1), 27-33.

Bublitz, W., \& Norrick, N. R. (Eds.). (2011). Foundations of pragmatics (Vol. 1). Walter de Gruyter.

Budiasih T. L, Andayani \& Rohmadi. M. (2017). Illocution in speech acts by foreign students in Indonesian as a foreign language classes. Indonesian Journal of Language Teaching and Linguistics, 2 (3), 213-226.

Creswell, J.W. (2014). Research design. Qualitative, quantitative, and mixed methods approaches. London: SAGE Publications.

Cumming, L. (2007). Pragmatik. Sebuah Perspektif Multidisipliner. Yogyakarta: Pustaka Pelajar.

Djajasudarma, T. F. (2009). Semantik 2 - Pemahaman Ilmu Makna. Bandung: Refika Aditama. 
Nafisah,I., Anday ani \& Wardani,N.E. (2019). Personal and spatial deixes amid foreign students in Muhammadiy ah University of

Gunawan, F. (2013). Wujud Kesantunan Berbahasa Mahasiswa Terhadap Dosen di STAIN Kendari: Kajian Sosiopragmatik. Journal Arbiter, 1 (1), 8-18.

Johnson, M. (2008). A philosophy of second language acquisition. Yale University Press.

Kennedy, D. (2012). Here is/where there/is: Some observations of spatial deixis in robert creeley's poetry. Journal of American Studies, 46(1), 73-87.

Levinson, S. C. (1983). Pragmatics. Cambridge: Cambridge University Press.

Mahsun. (2012). Metode Penelitian Bahasa: Tahapan Strategi, Metode, dan Tekhniknya. Jakarta: Rajawali Pers.

Moleong, L.J. (2014) Metodologi Penelitian Kualitatif. Bandung: Remaja Rosdakarya.

Nadar, F.X. (2009). Pragmatik dan Penelitian Pragmatik. Yogyakarta: Graha Ilmu.

Nurdini, N. (2017). Analisis penggunaan deiksis pada buku bahasa inggris kelas X Kurikulum 2013. LingTera, 4(2), 149-162.

Purwiyanti, Y., Suw andi, S., \& Andayani, N. F. N. (2017). Strategi Komunikasi Pemelajar Bahasa Indonesia bagi Penutur Asing Asal Filipina. Ranah: Jurnal Kajian Bahasa, 6(2), 160-179.

Purwo, B. K. (1984). Deiksis dalam Bahasa Indonesia. Jakarta: Balai Pustaka.

Putrayasa, I. B. (2014). Pragmatik. Yogyakarta: Graha Ilmu.

Saddhono, K. (2012). Kajian Sosiolingustik Pemakaian Bahasa Mahasiswa Asing dalam Pembelajaran Bahasa Indonesia untuk Penutur Asing (BIPA) di Universitas Sebelas Maret. Kajian Linguistik dan Sastra, 24(2), 176-186.

Sari, Y. (2018). Wujud Kesantunan Berbahasa Mahasiswa Asing Program Darmasiswa di Universitas Gadjah Mada. Jurnal Gramatika: Jurnal Penelitian Pendidikan Bahasa dan Sastra Indonesia, 4(1), 118-128.

Tonapa, Y., Anwar, M., \& Mantasiah, R. (2018). Analisis Kesalahan Penggunaan Deiksis dalam Karangan Sederhana Bahasa Jerman. Eralingua: Jurnal Pendidikan Bahasa Asing dan Sastra, 2(1), 55-62.

Yule, G. (2006). Pragmatik. Yogyakarta: Pustaka Pelajar. 